\title{
Computer aided planning of patches and conduits for surgery in congenital heart disease
}

\author{
Eugenié Riesenkampff ${ }^{*}$, Michael Huebler ${ }^{1}$, Urte Rietdorf ${ }^{2}$, Tobias Heimann², Tobias Schwarz², Hans-Peter Meinzer², \\ Felix Berger ${ }^{1}$, Titus Kuehne ${ }^{1}$
}

From 2011 SCMR/Euro CMR Joint Scientific Sessions

Nice, France. 3-6 February 2011

\section{Introduction and purpose}

To optimize outcome in congenital heart disease, the aim is to establish computer assisted methods for planning and simulating surgery in an objective and quantitative manner.

\section{Methods}

Based on 3D MRI datasets, two applications were developed: (1) for surgical correction of hypoplastic aortic arches the calculation of vessel diameters, and a patch for optimal surgical correction. This application was evaluated on 12 test datasets and phantoms. (2) For assessing the feasibility of biventricular repair in the case of complex cardiac malformations, an application for simulation of intracardiac repair with a Rastelli like procedure was developed and tested.

\section{Results}

(1) In all test datasets with varying aortic arch pathologies, diameters were determined with the new application with minor differences $(1.5 \pm 1.2 \mathrm{~mm})$ compared to the standard measurements. Individual patches were calculated. In phantoms (Goretex) of pathologic aortas, the patches were inserted successfully (Figure 1: Goretex phantom with partial (A) and fully (B) inserted patch). MRI thereafter revealed well-formed aortas. (2) Furthermore, an intracardiac conduit was computed for biventricular repair (Figure 1, panel C, D and E).

\section{Conclusions}

The calculation of patch material for surgical reconstruction of aortic pathologies is possible from 3D MRI data and first preclinical tests were successful. For com-

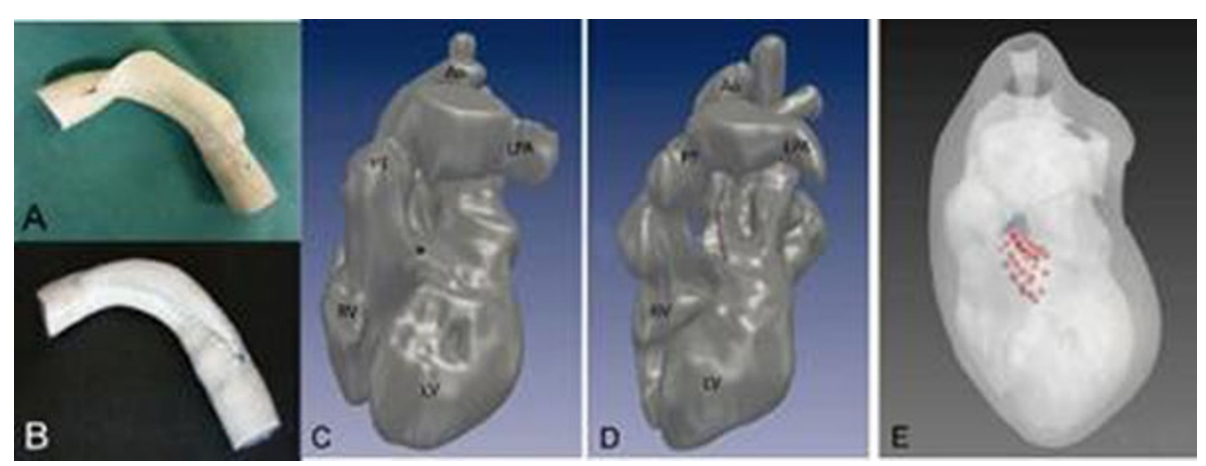

Figure 1

${ }^{1}$ German Heart Institute Berlin, Berlin, Germany

Full list of author information is available at the end of the article

(c) 2011 Riesenkampff et al; licensee BioMed Central Ltd. This is an open access article distributed under the terms of the Creative 
plex cardiac malformations, the preoperative evaluation of the operation method will be feasible. Further preclinical testing is needed.

\section{Author details}

${ }^{1}$ German Heart Institute Berlin, Berlin, Germany. ${ }^{2}$ German Cancer Research Center Heidelberg,Department of Medical and Biological Informatics,

Heidelberg, Germany.

Published: 2 February 2011

doi:10.1186/1532-429X-13-S1-P191

Cite this article as: Riesenkampff et al:: Computer aided planning of

patches and conduits for surgery in congenital heart disease. Journal of Cardiovascular Magnetic Resonance 2011 13(Suppl 1):P191.

Submit your next manuscript to BioMed Central and take full advantage of:

- Convenient online submission

- Thorough peer review

- No space constraints or color figure charges

- Immediate publication on acceptance

- Inclusion in PubMed, CAS, Scopus and Google Scholar

- Research which is freely available for redistribution

Submit your manuscript at www.biomedcentral.com/submit 